\title{
Temporal Variation in Photosynthetic Pigments and UV-Absorbing Compounds in Shallow Populations of Two Hawaiian Reef Corals ${ }^{1}$
}

\author{
Ilsa B. Kuffner ${ }^{2,3}$
}

\begin{abstract}
As we seek to understand the physiological mechanisms of coral bleaching, it is important to understand the background temporal variation in photosynthetic pigments and photoprotective compounds that corals exhibit. In this study, reef flat populations of two hermatypic coral species, Montipora capitata (Dana, 1846) and Porites compressa Dana, 1846, were sampled monthly in Kāne'ohe Bay, Hawai'i, from January 1998 to March 1999. Surface ultraviolet radiation (UVR) was measured continually during this time period at the same location. High-performance liquid chromatography (HPLC) analysis of photosynthetic pigments and mycosporine-like amino acids (MAAs) revealed temporal changes in concentrations and proportions of these compounds in tissues of both species of coral. Chlorophyll $a(\mathrm{chl} a)$, chlorophyll $c_{2}\left(\mathrm{chl} c_{2}\right)$, peridinin, and diadinoxanthin concentrations changed on a skeletal weight (M. capitata) or surface area ( $P$. compressa) basis, significantly correlating with seasonal changes in solar input (number of days from the winter solstice). In P. compressa, diadinoxanthin increased in proportion to the total pigment pool during summer months, suggesting an up-regulation of a xanthophyll cycle. In M. capitata, the ratio of chl $a$ : chl $c_{2}$ decreased during winter months, suggesting photoacclimation to lower light levels. It is surprising that there was not a clear seasonal pattern in total MAA concentration for either species, with the exception of shinorine in $P$. compressa. The relative stability of MAA concentrations over the course of the year despite a pronounced seasonal trend in UVR suggests either that MAAs are not performing a photoprotective role in these species or that concentrations are kept at a threshold level in the presence of a dynamic light environment.
\end{abstract}

A Clear understanding of the natural variation in coral pigmentation (both light harvesting and photoprotective compounds) is imperative as coral bleaching becomes more frequent and intense due to global cli-

${ }^{1}$ Funding was provided in part by an Edmondson Grant-in-Aid awarded to I.B.K. Manuscript accepted 21 December 2004.

${ }^{2}$ Department of Zoology, University of Hawaici, 2538 The Mall, Honolulu, Hawai'i 96822 and Hawai'i Institute of Marine Biology, P.O. Box 1346, Kāne‘ohe, Hawai'i 96744.

${ }^{3}$ Current address: U.S. Geological Survey, Center for Coastal and Watershed Studies, 600 4th Street South, St. Petersburg, Florida 33701 (e-mail: ikuffner@usgs.gov).

Pacific Science (2005), vol. 59, no. 4:561-580

(C) 2005 by University of Hawai'i Press

All rights reserved mate change (Høegh-Guldberg 1999). Corals and zooxanthellae have evolved a symbiosis in extremely high solar irradiance environments and a narrow range in sea surface temperature. The algal symbionts (zooxanthellae) resident in the gastrodermis of the coral animal require access to photosynthetically active radiation (PAR) $(400-750 \mathrm{~nm})$ for diurnal carbon gain, most of which is exported in support of the symbiosis (Muscatine et al. 1984). However, access to PAR comes at a price in the form of exposure to ultraviolet radiation (UVR) (280-400 nm). UVB (280$320 \mathrm{~nm}$ ) radiation is absorbed by and causes damage to nucleic acids and proteins (HolmHansen et al. 1993). In addition, the absorption of UVB and UVA (320-400 nm) by other cellular components can cause oxidative damage via the production of active oxygen species including singlet oxygen and oxygen, 
hydroperoxyl, and hydroxyl radicals (Dunlap and Yamamoto 1995). UVR can penetrate the water column down to $30 \mathrm{~m}$ in clear, oligotrophic waters commonly found in the tropics (Jerlov 1950, Smith and Baker 1979) and has been shown to play a role in coral bleaching (Gleason and Wellington 1993, Grottoli-Everett and Kuffner 1995).

Variability in the amount of photosynthetic pigment in corals has been recognized for a long time. As depth increases, so does the concentration of photosynthetic pigment per unit of coral surface area, manifested as an increase in pigment per algal cell (Chalker and Dunlap 1983, Falkowski et al. 1990, Masuda et al. 1993). Also, shade-acclimated colonies have zooxanthellae containing more pigment per algal cell than do light-acclimated colonies (Porter et al. 1984). Increases in photosynthetic pigment concentration per algal cell as depth increases have traditionally been interpreted as photoacclimation to offset decreases in light availability. Photoacclimation on a seasonal basis, however, has not been as well documented. Recent studies have shown an inverse relationship between zooxanthellae density and solar irradiance in natural populations, revealing a marked seasonal cycle in zooxanthellae densities for several species of coral wherein densities increase in the fall/winter (Stimson 1997, Fagoonee et al. 1999, Fitt et al. 2000). Other studies have documented high zooxanthellae densities during periods of decreased underwater PAR (during monsoon season: Brown et al. 1999b; due to increased turbidity: Cook et al. 2002). Most of those studies also document a wintertime increase in the amount of photosynthetic pigment per algal cell, but they measured only the chlorophylls.

Tissue concentrations of chl $a$ are often measured as the sole index of the lightharvesting capacity of the coral-algal symbiosis (see Table 3 in Kaiser et al. 1993), which in turn is often used as an indicator of the physiological state of the symbiosis. The historic trend of measuring only chl $a$ could be misleading because other pigments may also be responsive to changes in the solar irradiance regime (Chang et al. 1983, Iglesias-
Prieto and Trench 1997). The carotenoids, for example, may perform a photoprotective role by quenching excess irradiance, as demonstrated for the xanthophylls in free-living dinoflagellates (Demers et al. 1991) and recently for coral-algal symbioses (Brown et al. 1999a). In dinoflagellates, the light harvesting is accomplished with chl $a$ and the accessory pigments chl $c_{2}$ and peridinin (Iglesias-Prieto and Trench 1997). Only recently have the accessory photosynthetic pigments found in the zooxanthellae been considered with respect to coral ecology (Fang et al. 1995, Ambarsari et al. 1997, Helmuth et al. 1997, Myers et al. 1999).

A suite of UV-absorbing compounds found in the tissues of corals has been intensively investigated for their sun-screening potential (for reviews see Dunlap and Shick 1998, Gleason 2001, Shick and Dunlap 2002). Known as mycosporine-like amino acids (MAAs), these compounds have been found in orders-ofmagnitude higher concentrations in shallowdwelling corals compared with deep conspecifics (Dunlap et al. 1986, Banaszak et al. 1998). There has been debate over whether these UV-absorbing compounds actually benefit the coral as sunscreens; circumstantial evidence continues to mount in support of this contention, but direct evidence is scarce (Gleason 2001). Several species of coral increase concentrations of MAAs when transplanted from low to high irradiance environments (Scelfo 1986, Gleason and Wellington 1993). The naturally occurring, seasonal variation in MAA concentration in corals has received little attention (except see Drollet et al. 1997, Michalek-Wagner 2001 [soft corals]) but offers a natural experiment by which we can evaluate acclimation potential and the role of MAAs in UVR protection.

The aim of this study was to document temporal variability in photosynthetic pigments and photoprotective compounds in two species of corals in Hawai' $i$, both of which are major framework builders in the Hawaiian Islands. The two species were chosen based upon their importance in the local coral community, and because both are known to bleach (Jokiel and Brown 2004). 
Montipora capitata is generally more prone to bleach than Porites compressa, as observed during the 1996 massive bleaching episode in Hawaii (P. L. Jokiel, pers. comm.). To document background temporal trends in tissue concentrations of photosynthetic pigments and MAAs in these species, monthly tissue samples were extracted and measured using high-performance liquid chromatography (HPLC). Recording the changes in photosynthetic pigment concentrations throughout the year will increase our knowledge regarding the acclimation of corals to a dynamic light environment. Documenting temporal change in MAA concentrations, and correlating these fluctuations with UVR measured on site, could provide further evidence for the putative photoprotective role of these compounds.

\section{MATERIALS AND METHODS}

\section{Sample Collection}

Samples were collected monthly from the windward reef flat $(<1 \mathrm{~m}$ deep) of Coconut Island, Kāne'ohe Bay, Hawai'i $\left(21^{\circ} 25^{\prime} \mathrm{N}\right.$, $157^{\circ} 45^{\prime} \mathrm{W}$ ), from January 1998 to March 1999. Tidal range at this location is relatively small (mean range, $0.46 \mathrm{~m}$ ). One branch was collected from the top of three different colonies of two species, Porites compressa Dana, 1846, and Montipora capitata (Dana, 1846) (= Montipora verrucosa (Vaughan, 1907)), on 14 collection dates. Colonies were selected haphazardly; however, the probability that a single colony was sampled twice is very low, because the area sampled was approximately $600 \mathrm{~m}^{2}$. Samples were immediately transported to a $-50{ }^{\circ} \mathrm{C}$ freezer (in less than 5 min) and stored whole for up to 13 months until sample collection was complete. All samples were extracted for HPLC analysis during the same 2-week period in a randomized order.

\section{Solar Radiation Measurements}

Irradiance data were obtained from the weather station at the Hawai' $i$ Institute of
Marine Biology. UVR (295-385 nm) was measured with an Eppley Ultraviolet Radiometer (Eppley Laboratory, Inc., Newport, Rhode Island) in milliwatts per square centimeter $\left(\mathrm{mW} \mathrm{cm}^{-2}\right)$. Measurements were taken every $2 \mathrm{~min}$ and an average value recorded hourly. Hourly rates were then used to calculate a total dose of UVR for each day in $\mathrm{J} \mathrm{cm}^{-2}$ day $^{-1}$ by integrating the average over each hour. PAR data were also collected by the weather station, but intermittent sensor failure during the collection period precluded their use in this study. Solar irradiance measurements were also made with a scanning spectroradiometer (LiCor LI-1800UW, LiCor, Inc., Lincoln, Nebraska). Spectroradiometric scans were obtained for two cloudless days, one near the winter solstice (7 January 1998) and one close to the summer solstice (2 July 1998). These measurements allowed for the comparison of the quality of surface irradiance during the winter and summer.

\section{Sample Preparation}

All manipulations were performed in subdued lighting. Each coral was placed in a 50ml Falcon tube containing $10 \mathrm{ml}$ of $100 \%$ HPLC-grade methanol and sonicated surrounded by ice water for 6 min (Jeffrey et al. 1997). The extracts were then centrifuged at $4{ }^{\circ} \mathrm{C}$ for $2 \mathrm{~min}$ at $3,000 \mathrm{RPM}$ on a centrifuge (IEC Centra MP4R). The supernatant was decanted and stored at $-20{ }^{\circ} \mathrm{C}$. Reextraction occurred twice, adding the new supernatant to the appropriate previous supernatant, resulting in a total extraction volume of $30 \mathrm{ml}$ per coral sample. A $1.2-\mathrm{ml}$ aliquot of the pooled extract was then transferred to an amber HPLC autosampler vial, flushed with pure nitrogen gas, and analyzed for photosynthetic pigments within $5 \mathrm{hr}$ of extraction. A second aliquot of $1.2 \mathrm{ml}$ was transferred to a microcentrifuge tube and centrifuged at 7,000 RPM on a centrifuge (Eppendorf $5415 \mathrm{C})$ to eliminate particulate matter. The aliquot was then transferred to an amber autosampler vial and stored at $-20{ }^{\circ} \mathrm{C}$ for later analysis of MAAs. Pigment and MAA 
concentrations were normalized to surface area for $P$. compressa, determined using the aluminum foil technique (Marsh 1970), and dry skeletal mass for M. capitata. Dry skeletal mass was used for M. capitata because the surface area could not be readily measured due to the rugose nature of the skeleton.

HPLC Analysis of Mycosporine-like Amino Acids

The analysis of MAAs was performed by slightly modifying the procedures described in Dunlap and Chalker (1986) and Shick et al. (1992) on a Shimadzu HPLC system. MAAs were separated by reverse-phase isocratic HPLC on a Brownlee RP-8 column $(25 \mathrm{~cm}, 5 \mu \mathrm{m})$ protected by an RP-8 guard, in an aqueous mobile phase of $0.1 \%$ acetic acid and $40 \%$ methanol. Detection of peaks was via UV absorbance at 313 and $340 \mathrm{~nm}$, and flow rate was $0.8 \mathrm{ml} \mathrm{min}{ }^{-1}$. Identities of peaks were confirmed by co-chromatography with quantitative standards prepared by the author under the guidance of W. C. Dunlap (Australia Institute of Marine Science). Peaks were integrated using EZ-Chrom software, and quantification of the individual MAAs was accomplished using the quantitative standards for calibration.

\section{HPLC Analysis of Photosynthetic Pigments}

The analysis of the photosynthetic pigments was performed using a slightly modified version of the procedure described in Goericke and Repeta (1993). Pigments were separated by reverse-phase HPLC on a Brownlee RP-8 $(25 \mathrm{~cm}, 5 \mu \mathrm{m})$ column protected by an RP-8 guard using a binary gradient solvent system. Solvents A (MeOH:0.5 N aqueous ammonium acetate, $75: 25)$ and $\mathrm{B}(\mathrm{MeOH})$ were programmed on the following gradient (minutes; \% solvent A, \% solvent B): $(0 ; 100,0)$, $(20 ; 0,100),(25 ; 0,100),(33 ; 100,0)$. Detection was at $440 \mathrm{~nm}$, and the flow rate was $1 \mathrm{ml} \mathrm{min}{ }^{-1}$. Purified chl $a$ was purchased from Aldrich Chemical Company, Milwaukee, Wisconsin. Purified standards of chl $c_{2}$, peridinin, and diadinoxanthin were prepared by the laboratory of R. Bidigare (Department of Oceanography, University of Hawaici) using methods cited in Latasa et al. (1996).

\section{Statistical Analysis}

The total and individual photosynthetic pigments were regressed on the number of days from the nearest winter solstice (i.e., dates were assigned a number from 0 to 182). This index of solar input was chosen for its generalized nature reflecting the combined effects of sun angle and day length. In addition to total and individual pigments, the ratios chl $a: \operatorname{chl} c_{2}, \operatorname{chl} c_{2}$ :peridinin, peridinin : $\operatorname{chl} a$, diadinoxanthin: $\operatorname{chl} a$, and diadinoxanthin:total pigments were also examined as a measure of photoacclimation of the zooxanthellae (e.g., Helmuth et al. 1997). The total and individual MAAs were regressed on the accumulative amount of UVR measured during the 7 days before collection date. This time period was chosen because of results reported in Drollet et al. (1997), who found a 1-week lag in the correlation between the quantity of UVabsorbing compounds in coral mucus and amount of UVB radiation. Other UVR time periods before collection data were examined but are not reported here because they explained less of the variation in MAA concentration than the 1-week time period. If the assumptions of the regression models were not met as ascertained by normal probability plots and examination of the residuals, the data were transformed. Nonparametric Kruskal-Wallis one-way analysis of variance (ANOVA) was conducted for some variables to look for differences in means at different collection dates.

\section{RESULTS}

\section{Temporal Trends in Ultraviolet Radiation}

Integrated values of UVR in $\mathrm{J} \mathrm{cm}^{-2}$ day $^{-1}$ changed over the course of the year, and day-to-day variation was sometimes as great as the overall change throughout the period (Figure 1). The 1-week period before coral collection date with the highest accumulative UVR value was from 10 to 16 May 1998, with 


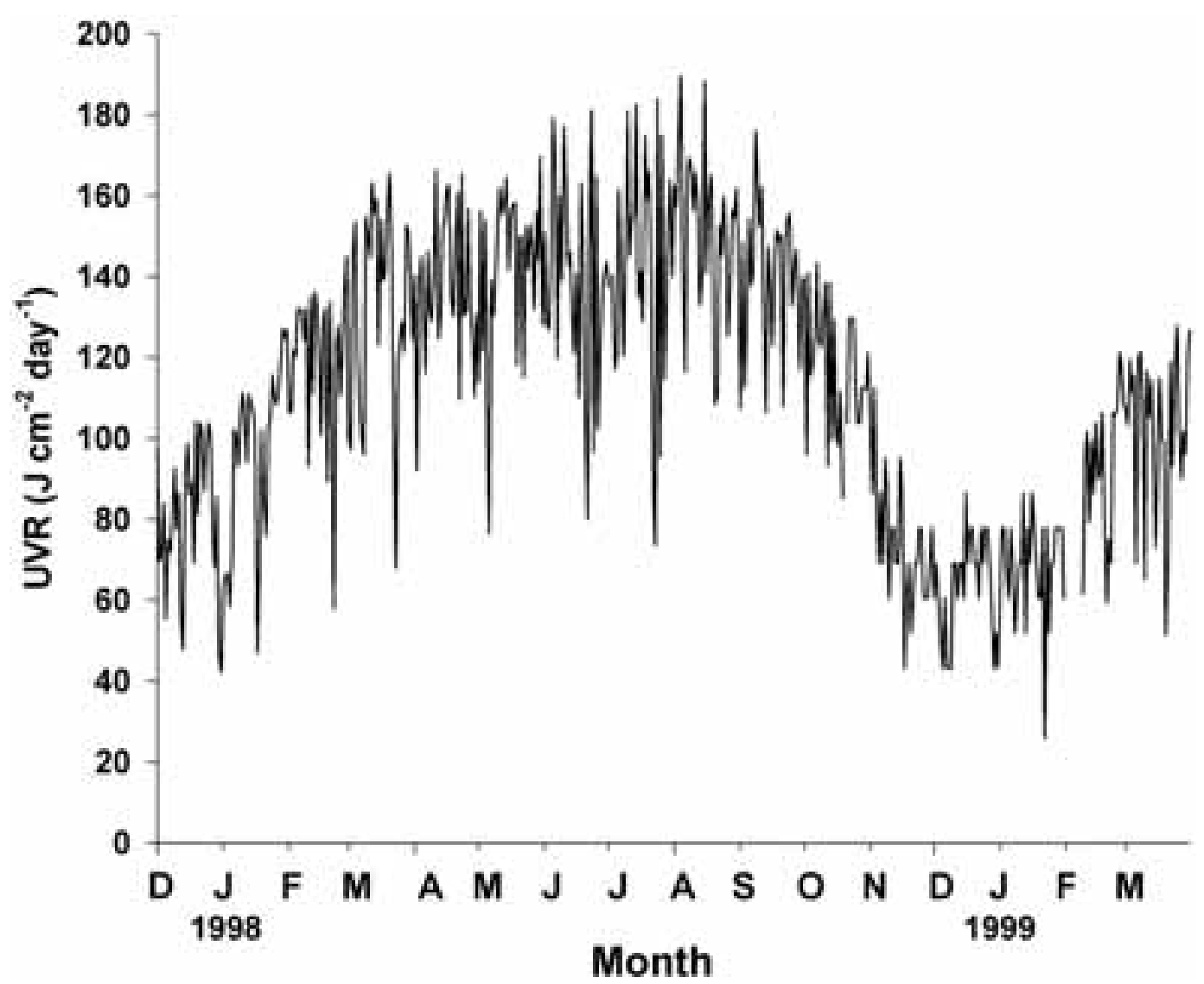

FIGURE 1. Daily insolation calculated from hourly averages of ultraviolet radiation (295-385 nm) from December 1997 to March 1999.

a value of $1,093 \mathrm{~J} \mathrm{~cm}^{-2}$. The lowest corresponding 1-week period value of $484 \mathrm{~J} \mathrm{~cm}^{-2}$ occurred between 11 and 17 December 1998. This winter value is $44 \%$ of the maximum summer value.

The quality of solar irradiance also changed on a temporal basis. Spectroradiometric measurements for two cloudless days, one near the winter solstice (7 January 1998) and one close to the summer solstice (2 July 1998), demonstrate that higher-energy wavelengths in the UV region attenuated more with time than did PAR (Table 1, Figure 2). These values represent the difference in solar quality between summer and winter under clear skies only, however, and changes due to

\section{TABLE 1}

Surface Irradiance on Two Cloudless Days within 20 Min of Maximum Sun Altitude for Integrated UVB (300-320 nm), UVA (320-400), UV (300-400 nm), and PAR (400-700) in $\mathrm{W} \mathrm{m}^{-2}$

\begin{tabular}{lccc}
\hline \hline Waveband & $\begin{array}{c}\text { 2 July } \\
1998\end{array}$ & $\begin{array}{c}\text { 7 Jan. } \\
1998\end{array}$ & $\begin{array}{c}\text { \% of } \\
\text { Summer } \\
\text { Value }\end{array}$ \\
\hline UVB & 4.02 & 2.21 & 55 \\
UVA & 59.54 & 39.55 & 66 \\
UV & 63.18 & 41.54 & 66 \\
PAR & 470.95 & 358.07 & 76 \\
PAR:UV & 7.45 & 8.62 & - \\
UVA:UVB & 14.8 & 17.9 & - \\
\hline
\end{tabular}




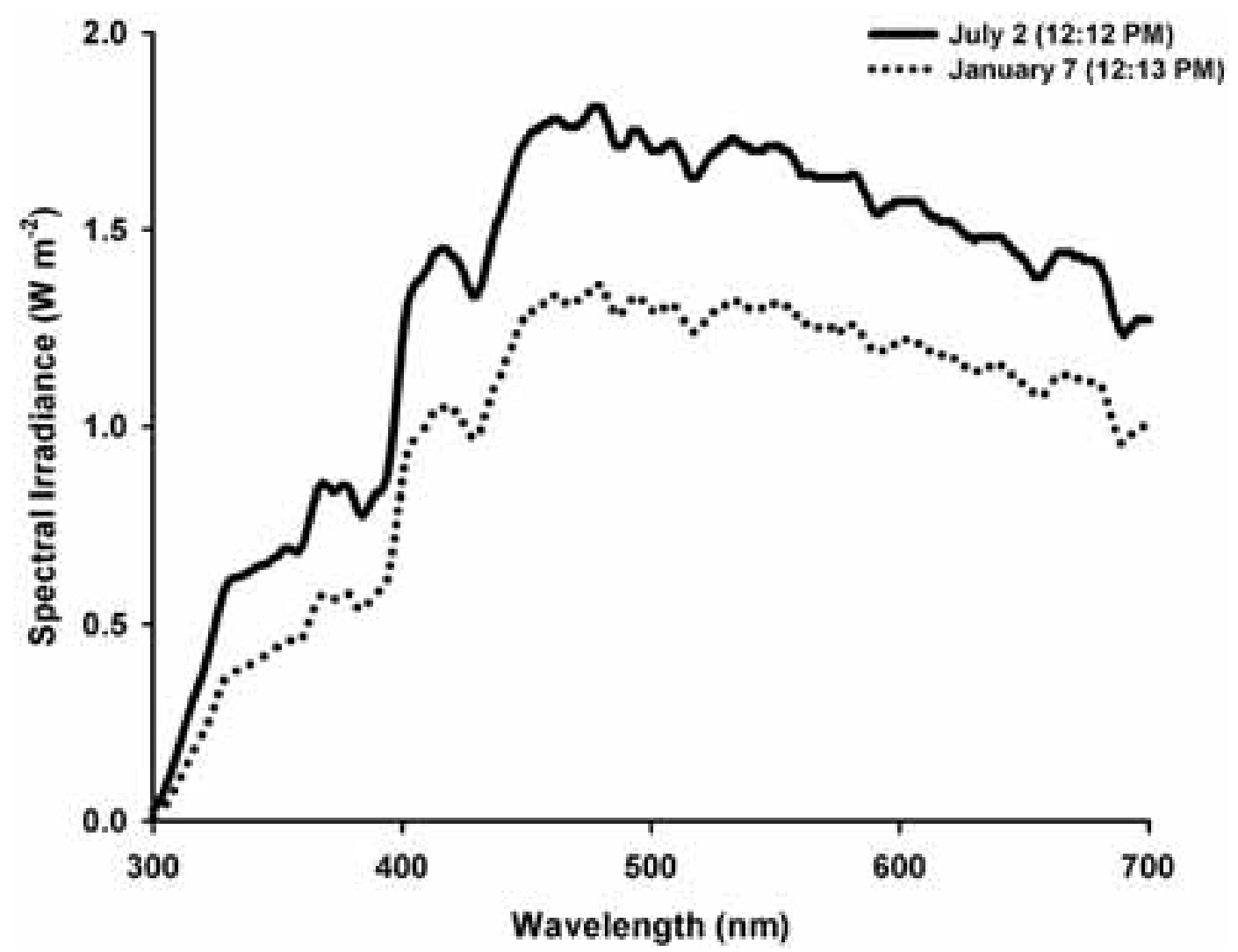

FIgURE 2. Spectral irradiance scans taken at the Hawaici Institute of Marine Biology on 7 January 1998 and 2 July 1998 within $20 \mathrm{~min}$ of maximum solar altitude.

meteorological conditions (i.e., cloud cover) can be large.

\section{Photosynthetic Pigments}

Four main photosynthetic pigments were found in the tissues of $P$. compress $a$ and $M$. capitata: the porphyrins $\operatorname{chl} a$ and $\operatorname{chl} c_{2}$, and the carotenoids peridinin and diadinoxanthin. Very small peaks (less than $2 \%$ total peak area) corresponding to the retention times for diatoxanthin and $\beta$-carotene were observed on the chromatograms, but these compounds were not quantified.

Maximum total pigment concentrations were found in the months of December and January for $P$. compressa and $M$. capitata, respectively (Figure 3). Regression analysis revealed a significant inverse relationship between the concentration of all four photosynthetic pigments of both species and the number of days from the winter solstice (Table 2, Figures 4 and 5). Number of days from winter solstice accounted for approximately $25 \%$ of the variation in total photosynthetic pigment concentration in both species.

In $P$. compressa, there was a clear positive relationship between diadinoxanthin:chl $a$ and diadinoxanthin:total pigments and the number of days from the solstice $\left(\mathrm{r}^{2}=0.158\right.$, $P<0.0092$ and $r^{2}=0.331, P<0.0001$, respectively). In $M$. capitata, the chl $a: \operatorname{chl} c_{2}$ ratio was significantly inversely correlated with number of days from the winter solstice (i.e., the ratio increased during winter months; $\left.\mathrm{r}^{2}=0.221, P<0.0017\right)$. Ratios among the other pigments did not exhibit a pattern over the course of the year. 

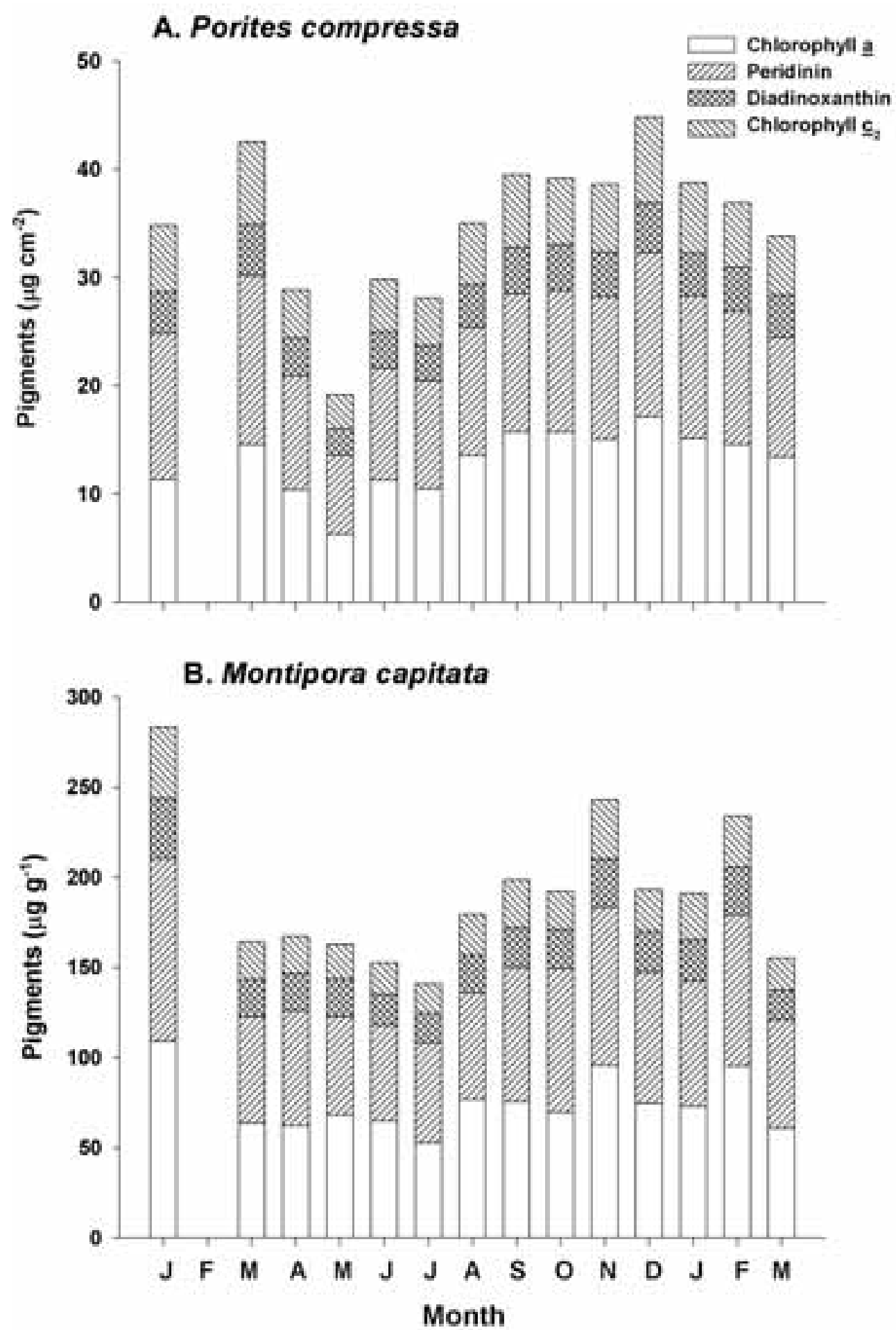

Figure 3. Total mean tissue concentration of photosynthetic pigments in $A$, Porites compressa and $B$, Montipora capitata at each of 14 collection dates from January 1998 to March $1999(n=3)$. 
TABLE 2

Results of Regression Analysis for Photosynthetic Pigments in the Tissues of Porites compressa and Montipora capitata on the Number of Days from the Winter Solstice (21 December)

\begin{tabular}{lcrrr}
\hline \hline Model & $\mathrm{R}^{2}$ & $F$ & $\mathrm{df}$ & $P^{a}<$ \\
\hline Porites compress $a$ & & & & \\
Total pigments $=43034-92.4$ (days) & 0.248 & 13.16 & 41 & $\mathbf{0 . 0 0 0 8}$ \\
Chlorophyll $a=16340-36.4$ (days) & 0.224 & 11.51 & 41 & $\mathbf{0 . 0 0 1 6}$ \\
Peridinin $=14816-30.7$ (days) & 0.246 & 13.08 & 41 & $\mathbf{0 . 0 0 0 8}$ \\
Diadinoxanthin $=4512.5-7.44$ (days) & 0.171 & 8.23 & 41 & $\mathbf{0 . 0 0 6 5}$ \\
Chlorophyll $c_{2}=7365.5-17.87$ (days) & 0.263 & 14.25 & 41 & $\mathbf{0 . 0 0 0 5}$ \\
Diadinoxanthin Chl $a=0.273+0.000352$ (days) & 0.158 & 7.49 & 41 & $\mathbf{0 . 0 0 9 2}$ \\
Diadinoxanthin : total pigments $=0.104+0.0000962$ (days) & 0.331 & 19.81 & 41 & $\mathbf{0 . 0 0 0 1}$ \\
Montipora capitata & & & & \\
Total pigments $=234464-512.4$ (days) & 0.249 & 13.28 & 41 & $\mathbf{0 . 0 0 0 8}$ \\
Chlorophyll $a=89525-173.6$ (days) & 0.181 & 8.81 & 41 & $\mathbf{0 . 0 0 5 0}$ \\
Peridinin $=87094-201.4$ (days) & 0.290 & 16.36 & 41 & $\mathbf{0 . 0 0 0 2}$ \\
Diadinoxanthin $=27015-56.6$ (days) & 0.188 & 9.25 & 41 & $\mathbf{0 . 0 0 4 1}$ \\
Chlorophyll $c_{2}=30830-80.9$ (days) & 0.288 & 16.21 & 41 & $\mathbf{0 . 0 0 0 2}$ \\
Chl $a$ :Chl $c_{2}=2.8843+0.00349$ (days) & 0.221 & 11.34 & 41 & $\mathbf{0 . 0 0 1 7}$ \\
\hline
\end{tabular}

${ }^{a} P$ values $<0.1$ are in boldface type.

\section{Mycosporine-like Amino Acids}

There were three MAAs identified in P. compressa: mycosporine-glycine, shinorine, and asterina-330, and five identified in M. capitata: mycosporine-glycine, shinorine, porphyra334, palythine, and palythene. There was also an unknown peak in the chromatograms of $P$. compressa, but the peak area was consistently less than $10 \%$ of the total peak area.

Temporal patterns in total MAA concentration were not clear, although springtime values tended to be highest (Figure 6). The total amount of UVR measured in the 1week time period before collection (UVR1) was not a good predictor of total MAA concentration in either species of coral. Regressing individual MAA concentrations on UVR1 revealed that only shinorine in $P$. compressa, and perhaps palythene in M. capitata, exhibited significant positive correlations with UVR (Table 3, Figures 6 to 8). UVR1 explained $22.8 \%$ of the variation in the concentration of shinorine (data square root transformed; $P<0.0014$ ) in $P$. compressa and $8.7 \%$ of the variation in palythene $(P<0.0574)$ in $M$. capitata (Figure 9). Shinorine concentrations in $M$. capitata did display significant differences with collec- tion date (Kruskal-Wallis one-way ANOVA, $P<0.050$ ), but power was insufficient to detect specific differences among the means.

Contrary to the patterns observed for the other MAAs, mycosporine-glycine concentrations in P. compressa appeared to decrease during the summer months of June, July, and August 1998 (Figure 7A), but the monthly means were not significantly different from one another (Kruskal-Wallis oneway ANOVA, $P<0.395)$. The estimated slope of the regression line was negative (Table 3), suggesting an inverse relationship between mycosporine-glycine concentration and UVR1; however, the relationship was weak and not significant $\left(\mathrm{r}^{2}=0.07, P<\right.$ 0.090).

\section{DISCUSSION}

In this study, concentrations of photosynthetic pigments and some UVR-absorbing compounds in the tissues of $P$. compress $a$ and $M$. capitata populations were observed to change significantly over the course of the year. Total photosynthetic pigment concentrations were at a maximum in winter months, nearly double the minimum values 

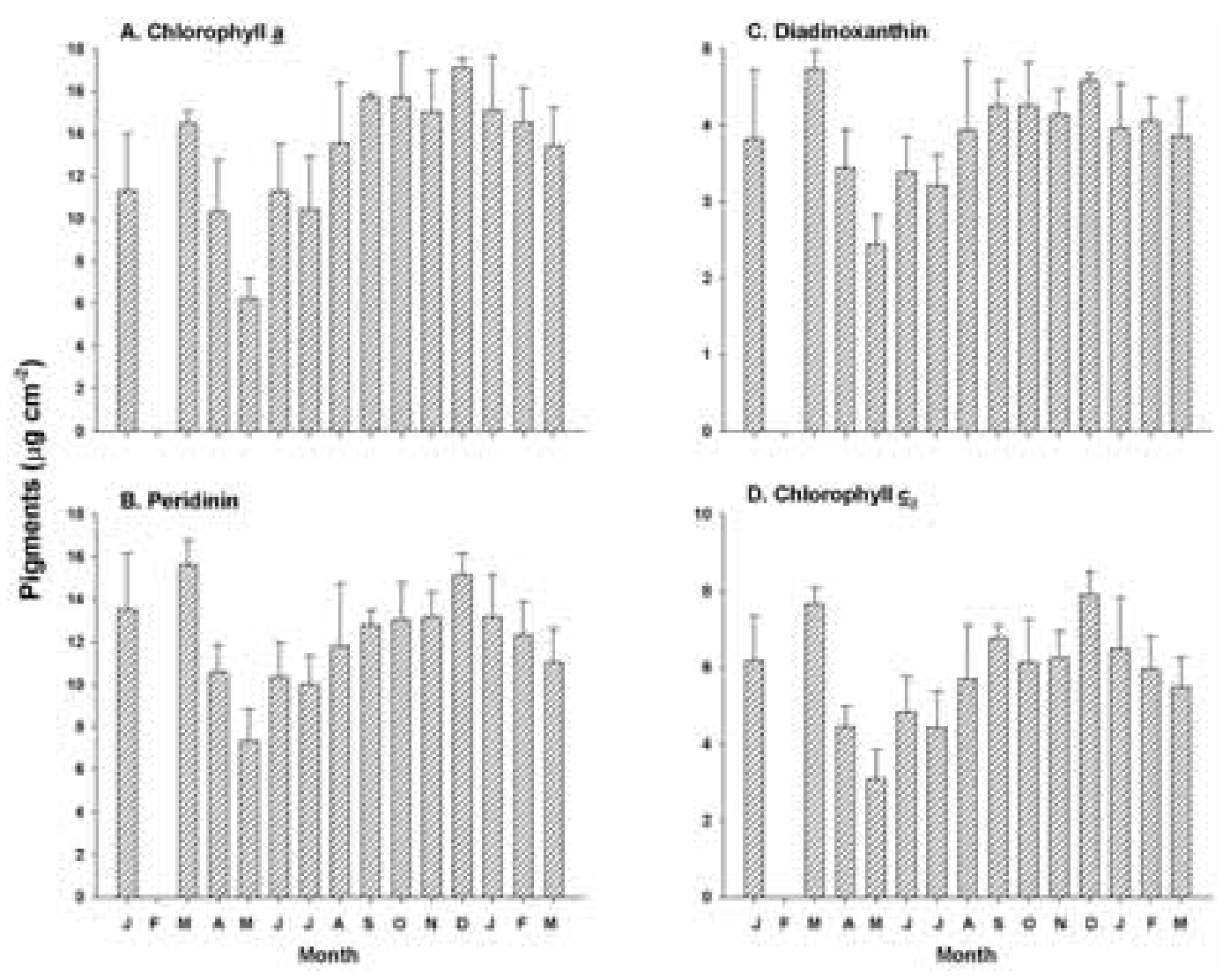

Figure 4. Porites compressa. Mean tissue concentration of photosynthetic pigments $(\mu \mathrm{g})$ normalized to surface area $\left(\mathrm{cm}^{-2}\right)$ at each of 14 collection dates from January 1998 to March 1999 ( $n=$ three different colonies). Four pigments were identified: $A$, chlorophyll $a ; B$, peridinin; $C$, diadinoxanthin; and $D$, chlorophyll $c_{2}$. Error bars represent one standard error.

observed in the summer. On the other hand, total MAA concentration was not correlated with accumulative UVR levels measured during the 1-week time period before collection. However, concentrations of shinorine in $P$. compressa did exhibit a significant positive relationship with UVR.

\section{Photosynthetic Pigments}

The results of this study provide evidence that the concentrations of photosynthetic pigments in P. compressa and M. capitata tissues vary over the course of the year, significantly correlating with seasonal changes in solar input (number of days from the winter solstice). Pigment levels approximately doubled in winter months compared with summer months. In M. capitata, the ratio $\operatorname{chl} a: \operatorname{chl} c_{2}$ significantly decreased in the winter, suggesting photoacclimation by the zooxanthellae to lower light levels by increasing photosynthetic unit size (Iglesias-Prieto and Trench 1997). In P. compressa, the proportion of diadinoxanthin making up the total pigment pool increased during the summer months. An increase in the total xanthophyll pool relative to total pigments was shown to occur in the coral Goniastrea aspera during a bleaching event in Thailand (Ambarsari et al. 1997). Also, cultured zooxanthellae from tropical symbioses become enriched in xanthophylls under supersaturating light conditions (Iglesias-Prieto and Trench 1997). In a free- 

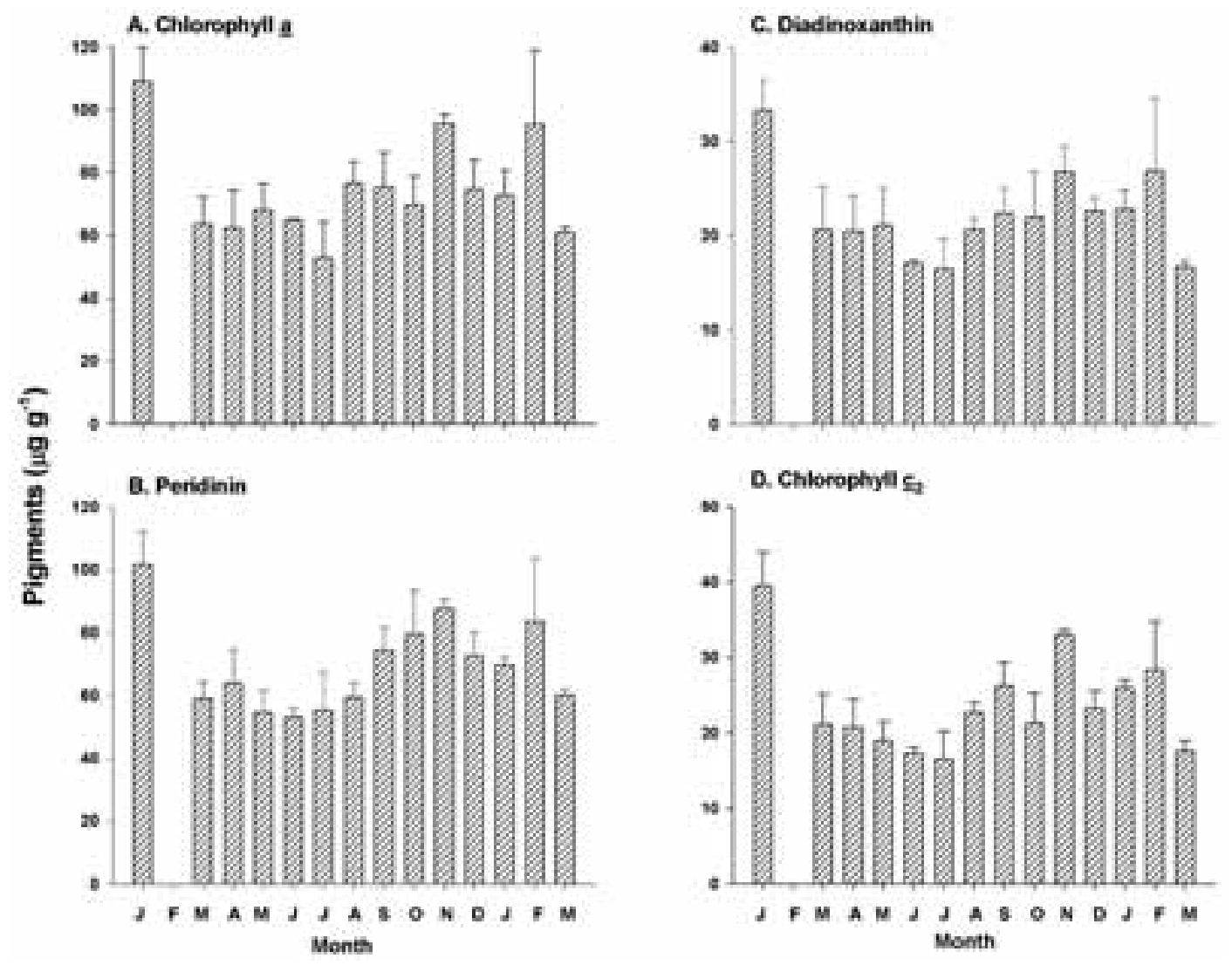

FIGURE 5. Montipora capitata. Mean tissue concentration of photosynthetic pigments $(\mu \mathrm{g})$ normalized to dry skeletal mass (g) at each of 14 collection dates from January 1998 to March 1999 ( $n=$ three different colonies). Four pigments were identified: $A$, chlorophyll $a$; $B$, peridinin; $C$, diadinoxanthin; and $D$, chlorophyll $c_{2}$. Error bars represent one standard error.

\section{TABLE 3}

Results of Regression Analysis for Mycosporine-like Amino Acids (MAAs) in the Tissues of Porites compressa and Montipora capitata on the Amount of Ultraviolet Radiation Measured during the 7 Days before Collection (UVR1)

\begin{tabular}{|c|c|c|c|c|}
\hline Model & $\mathrm{R}^{2}$ & $F$ & df & $P^{a}<$ \\
\hline \multicolumn{5}{|l|}{ Porites compressa } \\
\hline Total MAAs $=167.7-0.000142(\mathrm{UVR} 1)$ & 0.000 & 0.00 & 41 & 0.9948 \\
\hline Mycosporine-gly $=66.41-0.0213$ (UVR1) & 0.070 & 3.02 & 41 & 0.0902 \\
\hline Asterina-330 $=99.54+0.000152($ UVR 1$)$ & 0.000 & 0.00 & 41 & 0.9915 \\
\hline$\sqrt{ }$ Shinorine $=1.84+0.00283($ UVR 1$)$ & 0.228 & 11.8 & 41 & 0.0014 \\
\hline \multicolumn{5}{|l|}{ Montipora capitata } \\
\hline Total MAAs $=2206+0.495($ UVR 1$)$ & 0.029 & 1.20 & 41 & 0.2790 \\
\hline $\log _{10}$ Mycosporine-gly $=2.22+0.0000482(\mathrm{UVR} 1)$ & 0.008 & 0.35 & 41 & 0.5556 \\
\hline Palythine $=1860+0.4286($ UVR 1$)$ & 0.026 & 1.05 & 41 & 0.3127 \\
\hline Palythene $=102.2+0.0470($ UVR 1$)$ & 0.087 & 3.83 & 41 & 0.0574 \\
\hline$\sqrt{ }$ Porphyra-334 $=5.14+0.00243(\mathrm{UVR} 1)$ & 0.051 & 2.16 & 41 & 0.1499 \\
\hline $\log _{10}$ Shinorine $=1.38+0.000193($ UVR1) & 0.019 & 0.78 & 41 & 0.3832 \\
\hline
\end{tabular}

${ }^{a} P$ values $<0.1$ are in boldface type. 


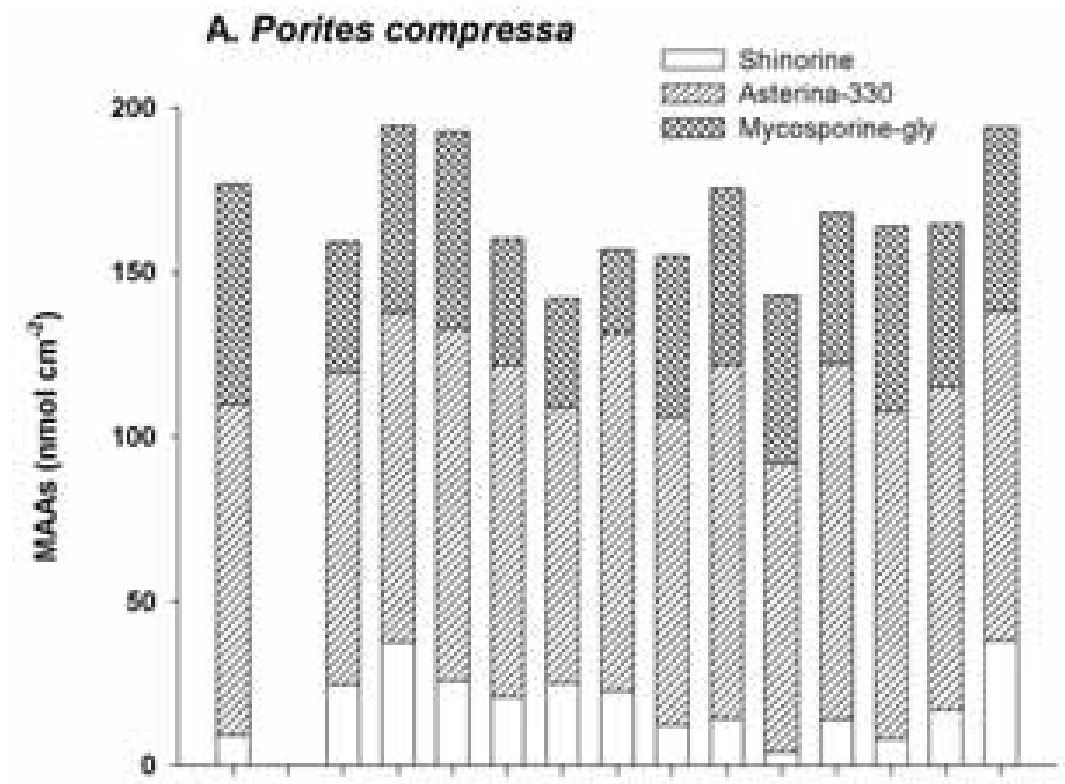

\section{B. Montipora capitata}

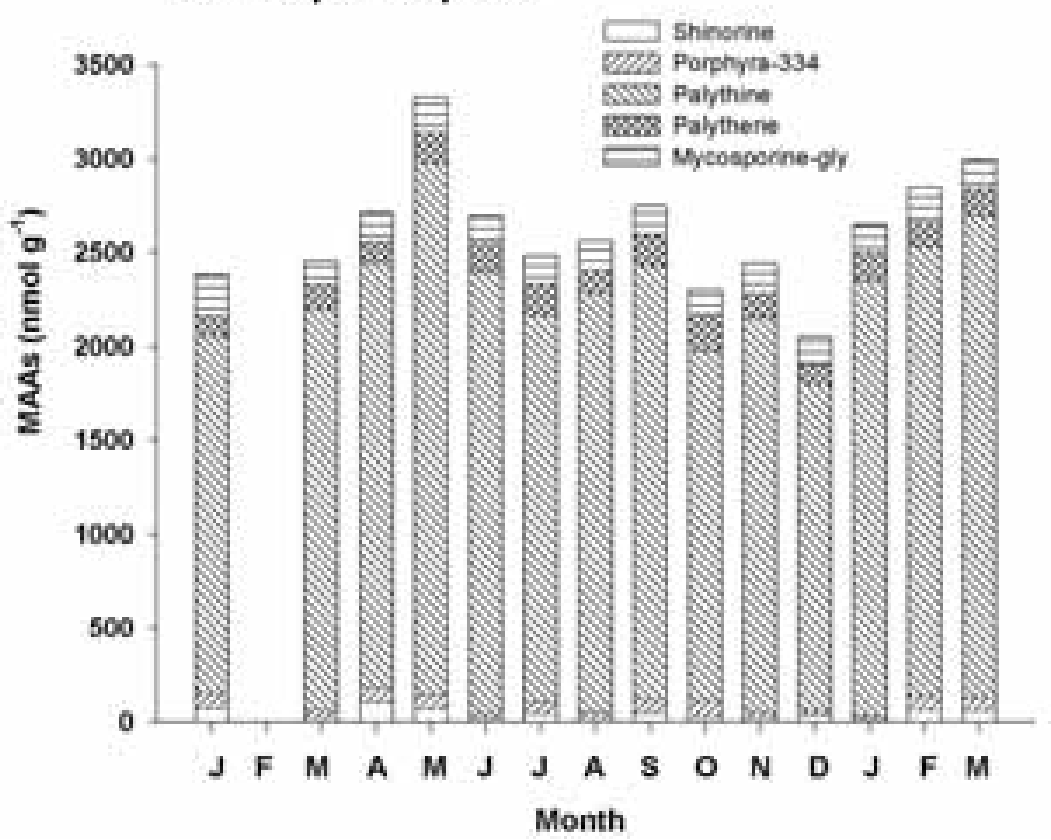

Figure 6. Total mean tissue concentration of mycosporine-like amino acids (MAAs) in A, Porites compressa and $B$, Montipora capitata at each of 14 collection dates from January 1998 to March $1999(n=3)$. 

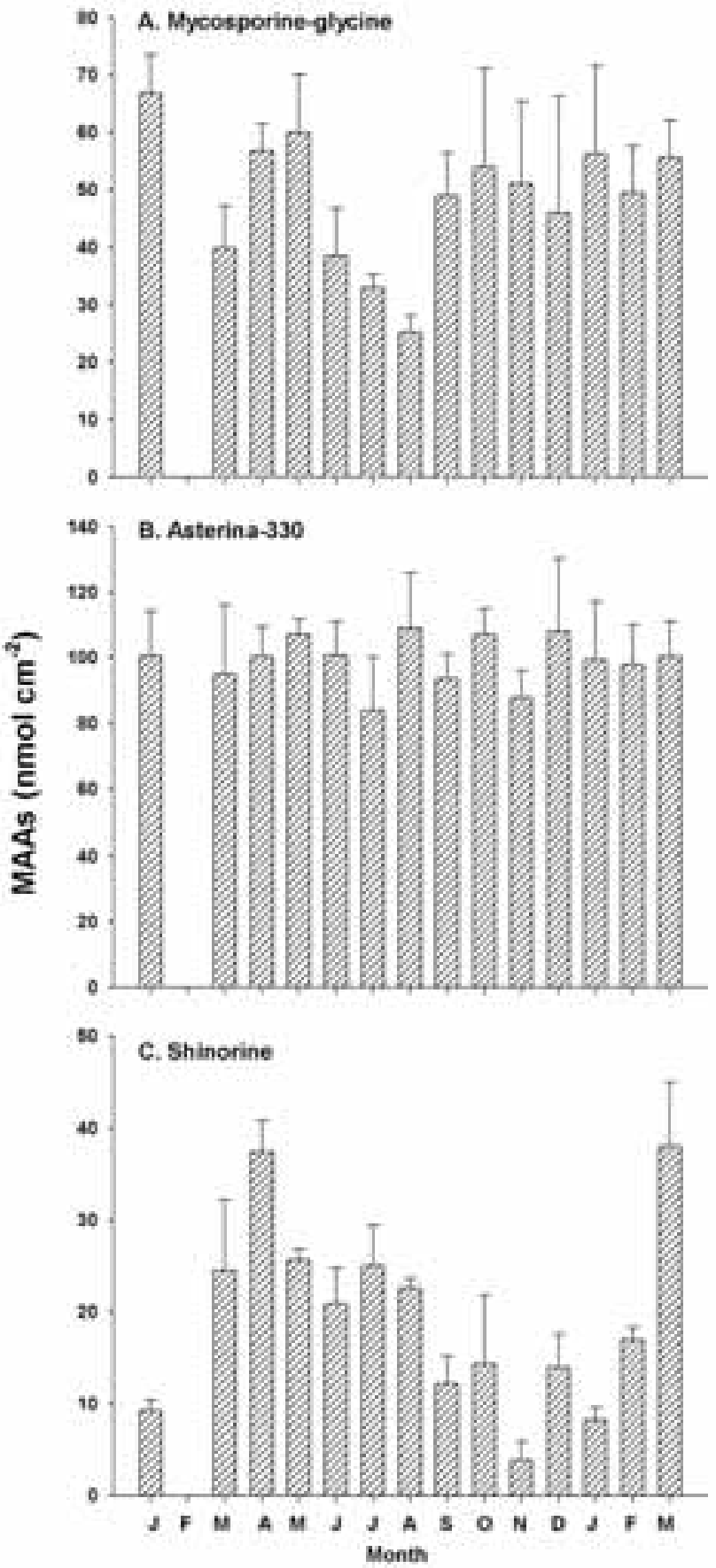

Figure 7. Porites compressa. Mean tissue concentration of mycosporine-like amino acids (MAAs, nmol) normalized to surface area $\left(\mathrm{cm}^{-2}\right)$ at each of 14 collection dates from January 1998 to March 1999 ( $n=$ three different colonies). Three MAAs were identified: $A$, mycosporine-glycine; $B$, asterina-330; and $C$, shinorine. Error bars represent one standard error. 

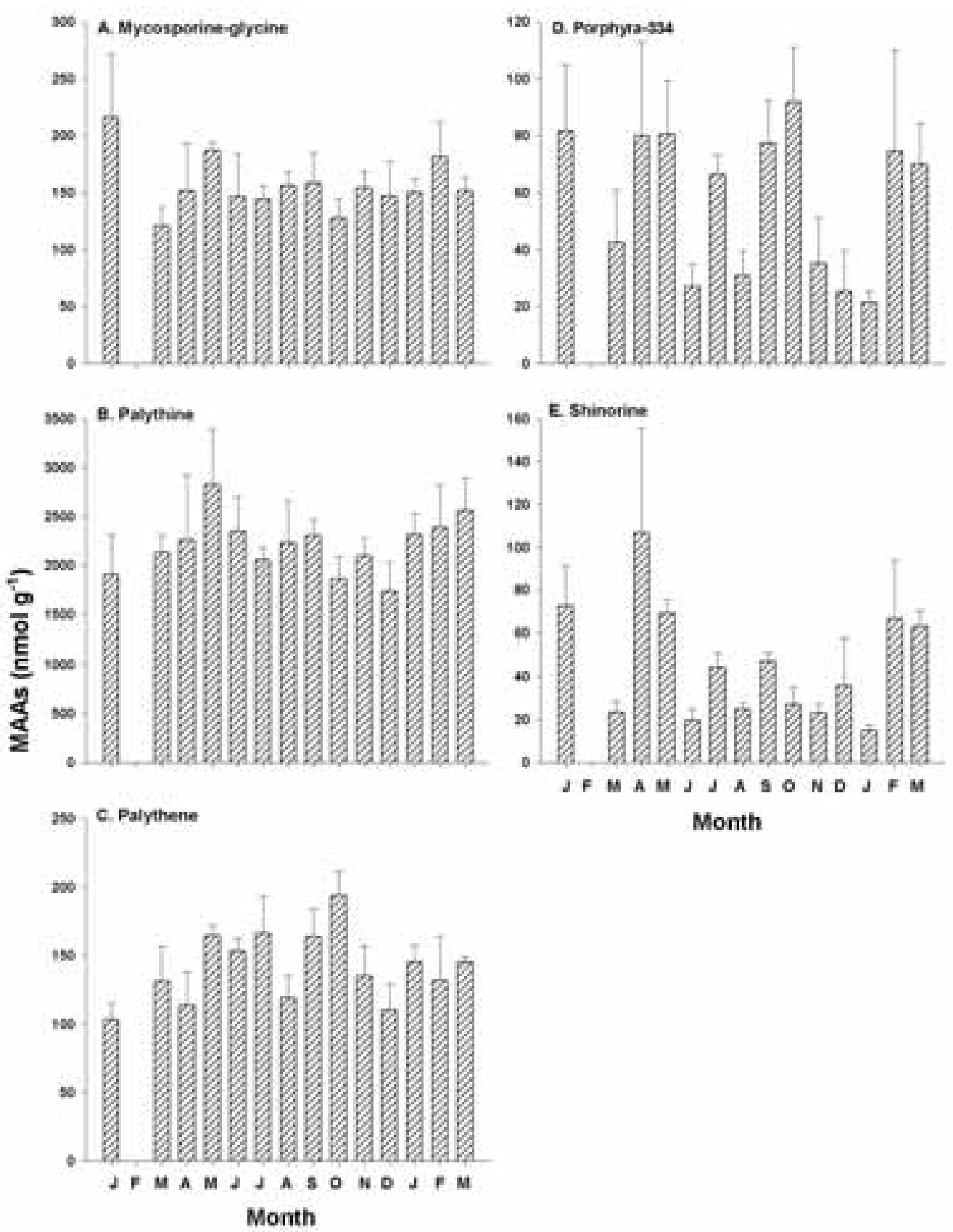

Figu RE 8. Montipora capitata. Mean tissue concentration of mycosporine-like amino acids (MAAs, nmol) normalized to dry skeletal mass $(\mathrm{g})$ at each of 14 collection dates from January 1998 to March $1999(n=3)$. Five MAAs were identified: $A$, mycosporine-glycine; $B$, palythine; $C$, palythene; $D$, porphyra-334; and $E$, shinorine. Error bars represent one standard error. 


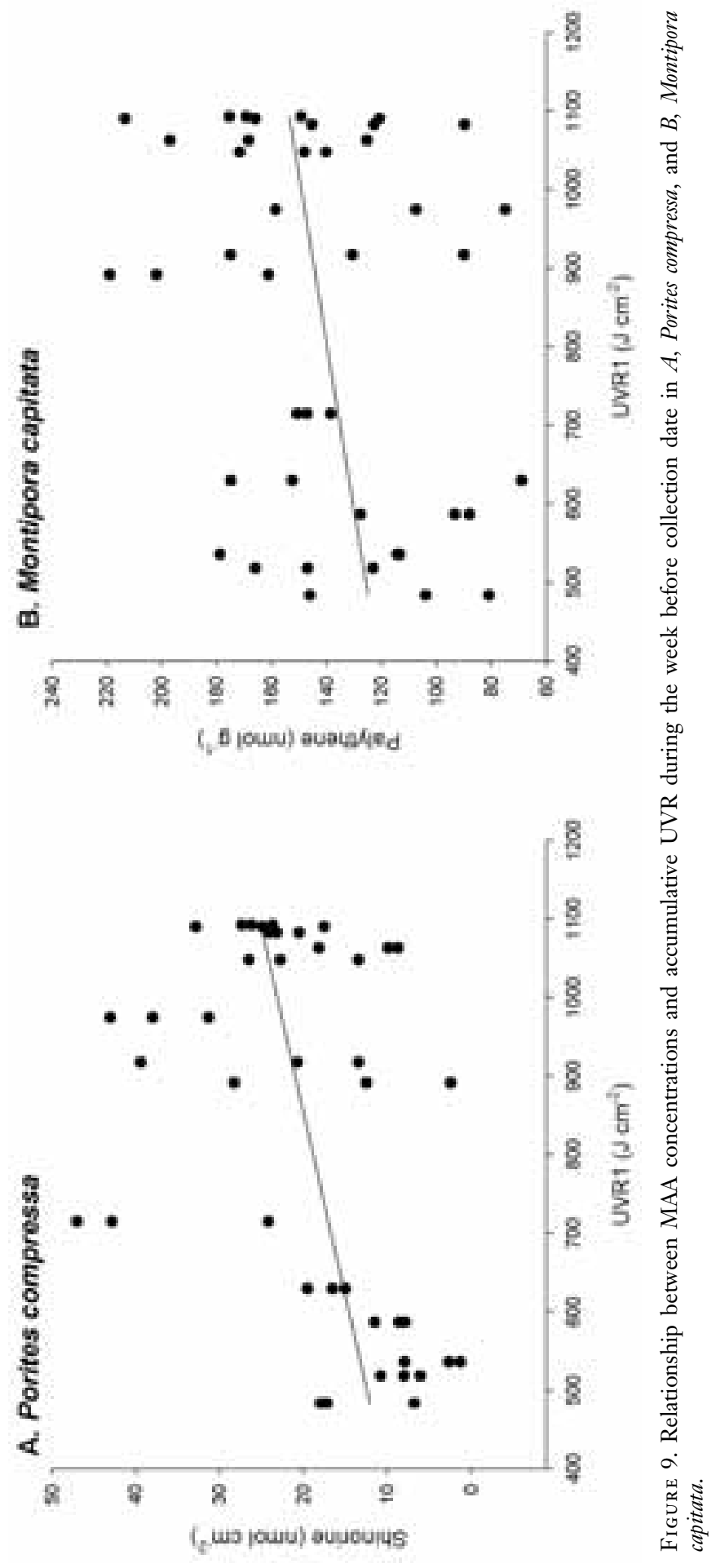


living dinoflagellate, diadinoxanthin is converted to diatoxanthin during periods of high light and is thought to dissipate excess light energy via fluorescence quenching (Demers et al. 1991). The existence of a xanthophyll cycle in coral-algal symbioses has been confirmed for Goniastrea aspera and Fungia fungites in Phuket, Thailand (Brown et al. $1999 a$ ) and suggested with strong evidence in two species of coral in Australia (HøeghGuldberg and Jones 1999). Unfortunately I was not able to quantify diatoxanthin during the analysis. Regardless, the presence of diadinoxanthin and its proportional increase to the total pigment pool during the summer months revealed in this study supports a hypothesized photoprotective function of this xanthophyll in the zooxanthellae of $P$. compressa.

The absence of a change in the proportion of diadinoxanthin to the total pigment pool in $M$. capitata in this study is especially interesting in light of research by Iglesias-Prieto and Trench (1997). One strain of zooxanthellae investigated in their study was isolated from $M$. verrucosa (= Montipora capitata in this study). Unlike the symbionts isolated from the jellyfish Cassiopeia xamachana and the zooanthid Zoanthus sociatus, the symbiont from $M$. capitata did not show evidence of being enriched with a xanthophyll in the cultures grown in supersaturating light levels. They concluded that the three symbioses exemplify different levels of photoacclimative plasticity, each appropriate to their distribution in nature, with $M$. capitata being the most "shade-loving" species of the three examined. In the study reported here, $P$. compressa showed evidence of pigment pool enrichment by a xanthophyll during highirradiance months, which is in accordance with its dominance on the reef flats in Kāne'ohe Bay. Although M. capitata is also common at these shallow depths, it did not show evidence of xanthophyll enrichment during the summer months in this study in agreement with Iglesias-Prieto and Trench (1997).

Changes in the density of zooxanthellae populations within coral tissues could also afford the coral-algal symbiosis some capac- ity for acclimation to changes in irradiance. Stimson (1997) documented an annual cycle in zooxanthella density within the tissues of Pocillopora damicornis in Hawai'i; mean density of zooxanthellae approximately doubled from summer to winter. Fagoonee et al. (1999) recorded the same phenomenon with $6 \mathrm{yr}$ of data for the coral Acropora formosa in Mauritius, finding that the densities of algal cells in autumn/winter were three times those in summer/spring. Fitt et al. (2000) found zooxanthellae densities following these same patterns in five species of corals in the Bahamas and also found a wintertime increase in chl $a$ per zooxanthella. The interpretation of this pattern has varied. Some researchers interpret the changes to be seasonal acclimation to lower levels of PAR (e.g., Stimson 1997), whereas others interpret the changes as "repetitive bleaching" in summer/fall (or dry season) resulting from high irradiance stress (Brown et al. 1999b, Fitt et al. 2000). In support of the second interpretation, most studies have shown that photoacclimation occurring along a depth gradient results from increases in pigment per zooxanthella and not an increase in zooxanthellar density (reviewed in Stimson 1997). Because zooxanthellae densities were not measured in the study reported here, I can only comment on the surface area specific increases in pigment concentration, but higher densities of zooxanthellae could have been partially responsible. However, because the relative proportions of photosynthetic pigments making up the total pigment pool changed in both species, zooxanthellae were probably photoacclimating, possibly by increasing the size and/or the number of light-harvesting antennae as light availability decreased. Another notion to consider is whether the coral host has any influence over symbiont densities; perhaps the coral compensates for lower rates of photosynthesis by allowing zooxanthellae populations to increase, conceivably by controlling access to dissolved inorganic nutrients (Rees 1991). In support of this, studies have shown that zooxanthellae are nutrient limited in hospit (Stambler et al. 1991, Muller-Parker et al. 1994). Stimson (1997) reported on one experiment that showed 
zooxanthellae growth to be $\mathrm{N}$-limited in winter but not during spring/summer. Fitt et al. (2000) suggested that the coral-algal symbiosis is living in suboptimal growth conditions in the summertime (using tissue biomass reduction as evidence) and "fattening up" in the winter. This interesting debate needs to be addressed experimentally, but I believe that my results support the notion that the coral-algal symbiosis acclimatizes to lower levels of PAR in the wintertime.

\section{Mycosporine-like Amino Acids}

When compared with the well-documented changes in MAA concentration along a depth gradient (Dunlap et al. 1986, Banaszak et al. 1998), the annual changes observed in this study seem small and unconvincing. When the accompanying changes in solar irradiance over these temporal/spatial scales are compared, however, the observed stability in MAA concentration becomes more understandable. Even in clear, oceanic water, irradiance is attenuated much more dramatically with depth than with season at tropical latitudes (Kirk 1994). As shown in the study reported here, the amount of UVR measured at maximum solar altitude on a cloudless, winter day was $66 \%$ of that on a summer day. For an attenuation coefficient typical of coastal reef waters $\left(\mathrm{K}_{\mathrm{dUVR}}=0.315\right)$, a $66 \%$ change in UVR occurs by a depth of only $1.2 \mathrm{~m}$. Studies documenting depth gradients in MAA concentration have typically sampled from 0 to $30 \mathrm{~m}$ wherein the light regime changes by orders of magnitude (e.g., Banaszak et al. 1998). However, as pointed out by Gleason (2001), coral reef organisms live in a dynamic UVR environment that can change on short temporal scales due to shifting conditions in the water column (e.g., changing turbidity, phytoplankton blooms, etc.). Also, wavelet focusing of light can cause shallowdwelling organisms to experience flashes of UVR (see fig. 3 in Kuffner 2001b). The study reported here was conducted on a population of corals living at $<1 \mathrm{~m}$ depth; it is possible that threshold levels of MAAs are sustained year-round in response to the daily exposure to UVR being so variable in space and time. In addition, other factors such as water motion can have effects on MAA concentrations found in coral tissues (Jokiel et al. 1997, Kuffner 2001a, 2002), and intercolony variation in MAA concentration can be pronounced, even in corals from the same habitat and depth (Hunter 1985, and see fig. 1 in Kuffner 2002).

A study by Drollet et al. (1997) in Tahiti documented a significant $\left(P<0.05, \mathrm{r}^{2}=\right.$ $0.31)$ correlation between in vivo absorbance (300 to $360 \mathrm{~nm}$ ) of mucus from 11 Fungia repanda colonies and UVR over an 80-week time interval. They found an even tighter correlation between the wavelength of maximum absorbance, which varied through time, and UVR dose $\left(P<0.05, \mathrm{r}^{2}=0.42\right)$, suggesting that some MAAs are more responsive to changes in the UVR environment than others. Results presented here support this notion and provide evidence that shinorine is the most responsive MAA in P. compressa. In an experiment investigating the kinetics of MAA production and accumulation, Shick et al. (1999) found that shinorine behaved differently than the other MAAs. When Stylophora pistillata colonies were irradiated with UVR, shinorine reached maximum levels early on in the experiment and then decreased with time; the authors hypothesized that shinorine may be a precursor to other MAAs (Shick et al. 1999). Similar results congruent with the bioconversion of shinorine into other MAAs have been shown for a temperate alga, as well (Franklin et al. 1999, Krabs et al. 2002). Early springtime increases in shinorine were observed for both species of coral in the study reported here, adding to the supportive evidence for this hypothesis. However, much work remains to be done to elucidate the induction stimuli and biosynthetic pathways for the different MAAs (Krabs et al. 2004).

Mycosporine-glycine in $P$. compressa decreased in the summer months typically associated with higher levels of PAR and longer day length. A similar reduction in mycosporine-glycine in association with high light levels was observed by Gleason (1993) when $P$. astreoides (green color morph) colo- 
nies were transplanted from 6 to $1 \mathrm{~m}$ depth. Antioxidant activity has been confirmed for mycosporine-glycine, and it is suggested that this compound can provide some protection against photooxidative stress induced by oxygen radicals in photoautotophic symbiosis (Dunlap and Yamamoto 1995). The observed decreasing trend in mycosporine-glycine during the summer months of the study reported here could reflect increased photooxidative stress associated with high irradiance levels resulting in the oxidation of mycosporineglycine; however, statistically robust support for this was lacking in this study, highlighting the need for further investigation.

\section{CONCLUSIONS}

The results of this study suggest that the coral-algal symbioses of $M$. capitata and $P$. compressa adjust photosynthetic and photoprotective capacity over the course of the year. Both symbioses approximately doubled concentrations of photosynthetic pigments during the winter months. In $M$. capitata, the pigment ratio chl $a: \operatorname{chl} c_{2}$ also increased during the winter. With regards to photoprotection, there was evidence for xanthophyll enrichment (increase in diadinoxanthin:total pigment ratio) during spring/summer months for $P$. compressa but not for $M$. capitata. Total MAA concentration was not well correlated with UVR exposure in either species, but the individual MAA shinorine showed a significant positive relationship with UVR in the $P$. compressa population, and there was a weak suggestion of a similar pattern for palythene in M. capitata. These MAAs are relatively minor components of the total MAA pools for both species, bringing into question the biological significance of the correlations to UVR that they suggest. The populations studied here were in very shallow water on the reef flat, where changes in water clarity, focusing of irradiance by wavelets, and changes in water depth due to tides all contribute to creating a highly dynamic light environment. In light of this, the relative stability in total MAA concentration over the course of the year is not too surprising.

\section{ACKNOWLEDGMENTS}

I thank C. M. Smith for generously providing laboratory space and access to the HPLC system. The hospitality shown by W. C. Dunlap and the Australia Institute of Marine Science during the fabrication of quantitative MAA standards is greatly appreciated, and I thank R. R. Bidigare (University of Hawai ii) for supplying the quantitative standards of photosynthetic pigments. Comments from P. L. Jokiel, E. Cox, R. A. Kinzie III, C. M. Smith, M. McFall-Ngai, J. M. Shick, and three anonymous reviewers greatly improved the paper.

\section{Literature Cited}

Ambarsari, I., B. E. Brown, R. G. Barlow, G. Britton, and D. Cummings. 1997. Fluctuations in algal chlorophyll and carotenoid pigments during solar bleaching in the coral Goniastrea aspera at Phuket, Thailand. Mar. Ecol. Prog. Ser. 159:303-307.

Banaszak, A. T., M. P. Lesser, I. B. Kuffner, and M. Ondrusek. 1998. Relationship between ultraviolet (UV) radiation and mycosporine-like amino acids (MAAs) in marine organisms. Bull. Mar. Sci. 63:617628.

Brown, B. E., I. Ambarsari, M. E. Warner, W. K. Fitt, R. P. Dunne, S. W. Gibb, and D. G. Cummings. 1999a. Diurnal changes in photochemical efficiency and xanthophyll concentrations in shallow water reef corals: Evidence for photoinhibition and photoprotection. Coral Reefs 18:99-105.

Brown, B. E., R. P. Dunne, I. Ambarsari, M. D. A. Le Tissier, and U. Satapoomin. 1999b. Seasonal fluctuations in environmental factors and variations in symbiotic algae and chlorophyll pigments in four Indo-Pacific coral species. Mar. Ecol. Prog. Ser. 191:53-69.

Chalker, B. E., and W. C. Dunlap. 1983. Bathymetric adaptations of reef-building corals at Davies Reef, Great Barrier Reef, Australia. II. Light saturation curves for photosynthesis and respiration. J. Exp. Mar. Biol. Ecol. 73:37-56. 
Chang, S. S., B. B. Prezelin, and R. K Trench. 1983. Mechanisms of photoadaptation in three strains of the symbiotic dinoflagellate Symbiodinium microadriaticum. Mar. Biol. (Berl.) 76:219-229.

Cook, C. B., E. M. Mueller, M. D. Ferrier, and E. Annis. 2002. The influence of nearshore waters on corals of the Florida reef tract. Pages 771-788 in J. W. Porter and K. G. Porter, eds. The Everglades, Florida Bay, and coral reefs of the Florida Keys: An ecosystem sourcebook. CRC Press, Boca Raton, Florida.

Demers, S., S. Roy, R. Gagnon, and C. Vignault. 1991. Rapid light-induced changes in cell fluorescence and in xanthophyllcycle pigments of Alexandrium excavatum (Dinophyceae) and Thalassiosira pseudonana (Bacillariophyceae): A photo-protection mechanism. Mar. Ecol. Prog. Ser. 76: 185-193.

Drollet, J. H., T. Teai, M. Faucon, and P. M. V. Martin. 1997. Field study of compensatory changes in UV-absorbing compounds in the mucus of the solitary coral Fungia repanda (Scleractinia:Fungiidae) in relation to solar UV radiation, sea-water temperature, and other coincident physiochemical parameters. Mar. Freshwater Res. 48:329-333.

Dunlap, W. C., and B. E. Chalker. 1986. Identification and quantitation of nearUV absorbing compounds (S-320) in a hermatypic scleractinian. Coral Reefs 5:155-159.

Dunlap, W. C., and J. M. Shick. 1998. Ultraviolet radiation-absorbing mycosporinelike amino acids in coral reef organisms: A biochemical and environmental perspective. J. Phycol. 34:418-430.

Dunlap, W. C., and Y. Yamamoto. 1995. Small-molecule antioxidants in marine organisms: Antioxidant activity of mycosporine-glycine. Comp. Biochem. Physiol. B Comp. Biochem. 112:105-114.

Dunlap, W. C., B. E. Chalker, and J. K. Oliver. 1986. Bathymetric adaptations of reef-building corals at Davies Reef, Great Barrier Reef, Australia. III. UV-B absorbing compounds. J. Exp. Mar. Biol. Ecol. 104:239-248.
Fagoonee, I., H. B. Wilson, M. P. Hassell, and J. R. Turner. 1999. The dynamics of zooxanthellae populations: A long-term study in the field. Science (Washington, D.C.) $283: 843-845$.

Falkowski, P. G., P. L. Jokiel, and R. A. Kinzie. 1990. Irradiance and corals. Pages 89-107 in Z. Dubinsky, ed. Coral reefs, Ecosystems of the world. Elsevier Science Publishers, Amsterdam.

Fang, L. S., C. W. Liao, and M. C. Liu. 1995. Pigment composition in different-colored scleractinian corals before and during the bleaching process. Zool. Stud. 34:10-17.

Fitt, W. K., F. K. McFarland, M. E. Warner, and G. C. Chilcoat. 2000. Seasonal patterns of tissue biomass and densities of symbiotic dinoflagellates in reef corals and relation to coral bleaching. Limnol. Oceanogr. 45:677-685.

Franklin, L. A., I. Yakovleva, U. Karsten, and K. Luning. 1999. Synthesis of mycosporine-like amino acids in Chondrus crispus (Florideophyceae) and the consequences for sensitivity to ultraviolet $\mathrm{B}$ radiation. J. Phycol. 35:682-693.

Gleason, D. F. 1993. Differential effects of ultraviolet radiation on green and brown morphs of the Caribbean coral Porites astreoides. Limnol. Oceanogr. 38:1452-1463. . 2001. Ultraviolet radiation and coral communities. Pages 119-149 in C. S. Cockell and A. R. Blaustein, eds. Ecosystems, evolution, and ultraviolet radiation. Springer-Verlag, New York.

Gleason, D. F., and G. M. Wellington. 1993. Ultraviolet radiation and coral bleaching. Nature (Lond.) 365:836-838.

Goericke, R., and D. J. Repeta. 1993. Chlorophylls $a$ and $b$ and divinyl chlorophylls $a$ and $b$ in the open subtropical North Atlantic Ocean. Mar. Ecol. Prog. Ser. 101:307313.

Grottoli-Everett, A. G., and I. B. Kuffner. 1995. Uneven bleaching within a coral colony in response to differing levels of solar radiation. Pages 115-120 in D. Gulko and P. Jokiel, eds. Ultraviolet radiation and coral reefs. Hawaici Inst. Mar. Biol. Tech. Rep. 41. Sea Grant, Honolulu, Hawai'i. 
Helmuth, B., B. Timmerman, and K. Sebens. 1997. Interplay of host morphology and symbiont microhabitat in coral aggregations. Mar. Biol. (Berl.) 130:1-10.

Høegh-Guldberg, O. 1999. Climate change, coral bleaching and the future of the world's coral reefs. Mar. Freshwater Res. 50:839-866.

Høegh-Guldberg, O., and R. J. Jones. 1999. Photoinhibition and photoprotection in symbiotic dinoflagellates from reef-building corals. Mar. Ecol. Prog. Ser. 183:73-86.

Holm-Hansen, O., D. Lubin, and E. W. Helbling. 1993. Ultraviolet radiation and its effects on organisms in aquatic environments. Pages 379-425 in A. R. Young, L. O. Bjorn, J. Moan, and W. Nultsch, eds. Environmental UV photobiology. Plenum Press, New York.

Hunter, C. L. 1985. Assessment of clonal diversity and population structure of Porites compressa (Cnidaria, Scleractinia). Pages 69-74 in Proceedings of the Fifth International Coral Reef Congress. Tahiti.

Iglesias-Prieto, R., and R. K. Trench. 1997. Acclimation and adaptation to irradiance in symbiotic dinoflagellates. II. Response of chlorophyll-protein complexes to different photon-flux densities. Mar. Biol. (Berl.) 130:23-33.

Jeffrey, S. W., R. F. C. Mantoura, and S. W. Wright. 1997. Phytoplankton pigments in oceanography: Guidelines to modern methods. United Nations Educational, Scientific and Cultural Organization, Paris.

Jerlov, N. G. 1950. Ultraviolet radiation in the sea. Nature (Lond.) 116:111-112.

Jokiel, P. L., and E. K. Brown. 2004. Global warming, regional trends and inshore environmental conditions influence coral bleaching in Hawaii. Global Change Biol. 10:1627-1641.

Jokiel, P. L., M. P. Lesser, and M. E. Ondrusek. 1997. UV-absorbing compounds in the coral Pocillopora damicornis: Interactive effects of UV radiation, photosynthetically active radiation, and water flow. Limnol. Oceanogr. 42:1468-1473.

Kaiser, P., D. Schlichter, and H. Fricke. 1993. Influence of light on algal symbionts of the deep water coral Leptoseris fragilis. Mar. Biol. (Berl.) 117:45-52.

Kirk, J. T. O. 1994. Light and photosynthesis in aquatic ecosystems. 2nd ed. Cambridge University Press, Cambridge.

Krabs, G., K. Bischof, D. Hanelt, U. Karsten, and C. Wiencke. 2002. Wavelengthdependent induction of UV-absorbing mycosporine-like amino acids in the red alga Chondrus crispus under natural solar radiation. J. Exp. Mar. Biol. Ecol. 268:6982.

Krabs, G., M. Watanabe, and C. Wiencke. 2004. A monochromatic action spectrum for the photoinduction of the UVabsorbing mycosporine-like amino acid shinorine in the red alga Chondrus crispus. Photochem. Photobiol. 79:515-519.

Kuffner, I. B. 2001a. Effects of ultraviolet radiation and water motion on the reef coral Porites compressa Dana: A flume experiment. Mar. Biol. (Berl.) 138:467-476.

. 2001b. Effects of ultraviolet radiation on larval recruitment of the reef coral, $P_{0-}$ cillopora damicornis. Mar. Ecol. Prog. Ser. 217:251-261.

. 2002. Effects of ultraviolet radiation and water motion on the reef coral, Porites compressa Dana: A transplantation experiment. J. Exp. Mar. Biol. Ecol. 270:147169.

Latasa, M., R. R. Bidigare, M. E. Ondrusek, and M. C. Kennicutt II. 1996. HPLC analysis of algal pigments: A comparison exercise among laboratories and recommendations for improved analytical performance. Mar. Chem. 51:315-324.

Marsh, J. A., Jr. 1970. Primary productivity of reef-building calcareous red algae. Ecology 51:255-263.

Masuda, K., M. Goto, T. Maruyama, and S. Miyachi. 1993. Adaptation of solitary corals and their zooxanthellae to low light and UV radiation. Mar. Biol. (Berl.) 117:685-691.

Michalek-Wagner, K. 2001. Seasonal and sex-specific variations in levels of photoprotecting mycosporine-like amino acids (MAAs) in soft corals. Mar. Biol. (Berl.) 139:651-660.

Muller-Parker, G., L. R. McCloskey, O. 
Høegh-Guldberg, and P. J. McAuley. 1994. Effect of ammonium enrichment on animal and algal biomass of the coral Pocillopora damicornis. Pac. Sci. 48:273-283.

Muscatine, L., P. G. Falkowski, J. W. Porter, and Z. Dubinsky. 1984. Fate of photosynthetic fixed carbon in light- and shadeadapted colonies of the symbiotic coral Stylophora pistillata. Proc. R. Soc. Lond. B Biol. Sci. 222:181-202.

Myers, M. R., J. T. Hardy, C. H. Mazel, and P. Dunstan. 1999. Optical spectra and pigmentation of Caribbean reef corals and macroalgae. Coral Reefs 18:179-186.

Porter, J. W., L. Muscatine, Z. Dubinsky, and P. G. Falkowski. 1984. Primary production and photoadaptation in light- and shadeadapted colonies of the symbiotic coral, Stylophora pistillata. Proc. R. Soc. Lond. B Biol. Sci. 222:161-180.

Rees, T. A. V. 1991. Are symbiotic algae nutrient deficient? Proc. R. Soc. Lond. B Biol. Sci. 243:227-233.

Scelfo, G. M. 1986. Relationship between solar radiation and pigmentation of the coral Montipora verrucosa and its zooxanthellae. Pages 440-451 in P. L. Jokiel, R. H. Richmond, and R. A. Rogers, eds. Coral reef population biology. Hawai'i Inst. Mar. Biol. Tech Rep. 37. Honolulu.

Shick, J. M., and W. C. Dunlap. 2002.
Mycosporine-like amino acids and related gadusols: Biosynthesis, accumulation, and UV-protective functions in aquatic organisms. Annu. Rev. Physiol. 64:223-262.

Shick, J. M., W. C. Dunlap, B. E. Chalker, A. T. Banaszak, and T. K. Rosenzweig. 1992. Survey of ultraviolet radiation-absorbing mycosporine-like amino acids in organs of coral reef holothuroids. Mar. Ecol. Prog. Ser. 90:139-148.

Shick, J. M., S. Romaine-Lioud, C. Ferrier-Pages, and J. P. Gattuso. 1999. Ultraviolet-B radiation stimulates shikimate pathway-dependent accumulation of mycosporine-like amino acids in the coral Stylophora pistillata despite decreases in its population of symbiotic dinoflagellates. Limnol. Oceanogr. 44:1667-1682.

Smith, R. C., and K. S. Baker. 1979. Penetration of UV-B and biologically effective dose-rates in natural waters. Photochem. Photobiol. 29:311-323.

Stambler, N., N. Popper, Z. Dubinsky, and J. Stimson. 1991. Effects of nutrient enrichment and water motion on the coral Pocillopora damicornis. Pac. Sci. 45:299-307.

Stimson, J. 1997. The annual cycle of density of zooxanthellae in the tissues of field and laboratory-held Pocillopora damicornis (Linnaeus). J. Exp. Mar. Biol. Ecol. 214: $35-48$. 